\title{
EFFECTS OF WELDING CURRENT AND ARC VOLTAGE ON FCAW WELD BEAD GEOMETRY
}

\author{
Memduh Kurtulmus ${ }^{1}$, Ahmet İrfan Yukler ${ }^{2}$, Mustafa Kemal Bilici ${ }^{3}$, Zarif Catalgol ${ }^{4}$ \\ ${ }^{1}$ School of Applied Sciences,Marmara University, Istanbul, Turkey \\ ${ }^{2}$ Technology Faculty, Marmara University, Istanbul, Turkey \\ ${ }^{3}$ School of Applied Sciences, Marmara Universit, Istanbul, Turkey \\ ${ }^{4}$ Technical Education Faculty, Marmara University, Istanbul, Turkey
}

\begin{abstract}
Flux cored arc welding $(F C A W)$ process is characterized with its high deposition rate and productivity. Control of the operating parameters in FCAW is essential to obtain high production rates and good quality welds. Bead on plate welds were carried out on mild steel plates to study the influence of welding current and arc voltage on weld bead geometry parameters. The weld bead coss-sections were metallographically investigated. The effects of these welding parameters were evaluated by measuring penetration depth, reinforcement height, bead width, wetting angle, electrod deposit area and plate fusion area. The bead crosssection area and the weld shape factor were calculated from the measured results. The effects of welding parameters on weld bead geometry have been presented by histograms.
\end{abstract}

Key Words: Flux cored arc welding, arc welding parameters, weld bead geometry, weld shape factor

\section{INTRODUCTION}

Flux cored arc welding (FCAW) is a fusion welding achieved by an electric arc produced between a continuous filler metal electrode and the weld pool [1]. In this method the filler metal of tubular shape is continuously fed and has a fluxed core which provides shielding capabilities to the welding process with or without additional shielding from an externally supplied protection gas. The core is mainly formed by slag formers, deoxidizers, arc stabilizers, and alloying elements. FCAW method have received great attention from welders and contractors because flux cored wire have a lot of advantages such as outstanding productivity, high quality welds, deep penetration, spatter reduced welding behavior, higher deposition rates, high welding speed and cost advantages [2]. FCAW may be applied semi automatically or automatically. The FCAW process has become a very popular semiautomatic process for structural steel fabrication [3],shipyard Works [4] and repairs [5-7]. FCAW is also readily accepted for weld cladding $[8,9]$.

The profile of a weld bead geometry and its geometry parameters are schematically shown in Figure 1[10]. Weld geometry parameters are represented by bead width (W), height of reinforcement $(\mathrm{H})$, depth of penetration (D), wetting angle $(\theta)$, electrode deposit area $\left(\mathrm{A}_{\mathrm{d}}\right)$ and plate fusion area $\left(\mathrm{A}_{\mathrm{m}}\right)$. These parameters are measured on images of weld beads. The weld bead cross-section area $\left(A_{t}\right)$ is calculated by adding the electrode deposit area to the plate fusion area. Many researchers accepted the ratio of weld penetration depth to the weld width $(\mathrm{D} / \mathrm{W})$ is an important parameter to describe the weld profile [11-13]. This parameter is named as weld shape factor [14]. The weld bead geometry is directly dependent on welding parameters [15]. The cross-sectional area of the bead detemines the cooling rate of the weldment [16]. Bead cross-sectional area [17] and the ratio of penetration depth to weld width [10] determine the residual stresses and cracking of the weldment. Due to the above reasons, the quality and mechanical properties of weldments are dependent on size and shape of the weld bead [18,19]. Welding parameters must be optimized in order to obtain a good weld joint with the required bead geometry and weld quality [20]. There are also several publications about optimizations of the FCAW process by weld bead geometry analysis [21-35]. In these studies especially the effects of FCAW welding current, welding speed, arc voltage, electrod angle and nozzle to plate distance were investigated. The effects of these welding parameters on weld penetration depth, weld width and weld cross-sectional area were determined.

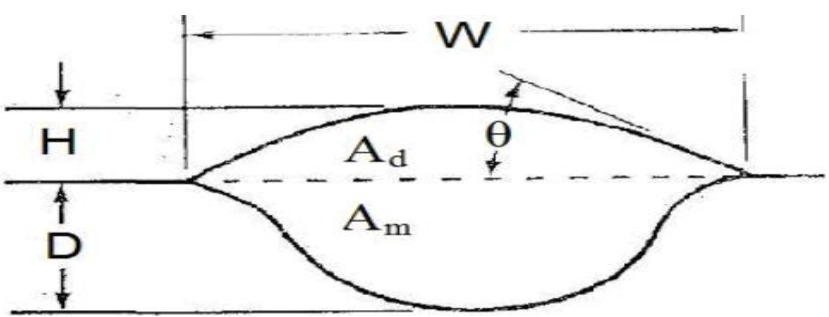

Fig-1: Geometry parameters of a bead on plate weld 10).

$\mathrm{A}_{\mathrm{d}}$ : Electrode deposit area, $\mathrm{A}_{\mathrm{m}}$ : Plate fusion area, D:

Penetration depth, H: Reinforcement height, W: Bead width, $\theta$ : Wetting angle

In this study the influence of the welding current and the arc voltage on weld bead geometry were investigated. These two welding parameters are very importanat in arc welding processes. In electric arc welding operations the heat input 
per unit length of the weld bead is calculated by equation 1 [36]:

$$
\mathrm{H}=\frac{\mathrm{I}-\mathrm{E}}{\mathrm{S}} \mathbf{I}
$$

where $\mathrm{I}=$ welding current (Amperes), $\mathrm{E}=$ arc voltage (volts), $\mathrm{S}=$ welding speed $(\mathrm{mm} / \mathrm{s})$ and $\mathrm{f}=$ arc efficiency percentage.

\section{EXPERIMENTS}

In this investigation, $10 \mathrm{~mm}$ thick SAE 1015 steel plates were used. The plates were sawed into 350x100 mm stripes. Prior to the welding operations, the surface of stripes were cleaned with an abrasive wheel. Bead on plate welds were carried out using a semi automatic Askaynak Magtronik 500 W FCAW welding machine. The speed of the torch was controlled with a mechanized system and during each welding operation the welding speed was kept costant at 4 $\mathrm{mm} / \mathrm{s}$ speed. The welding torch was kept at an inclination of $80^{\circ}$ to the pull direction. AWS E71T-5 basic filler wire of diameter $1.2 \mathrm{~mm}$ was used in welding. In all the welding operations the distance between the work piece and the contact tip was fixed at $19.5 \mathrm{~mm}$. Preheating was not used in welding operations. $\mathrm{CO}_{2}$ shielding gas flow was kept at $12 \mathrm{lt} / \mathrm{min}$. A $300 \mathrm{~mm}$ long weld was produced on each stripe. Three welds were produced at flat positions. The welding parameters and calculated heat input energy of the welds are shown in Table 1. The arc efficiency factor was accepted as \%86 [37] for calculating the heat input.

Table-1: The welding parameters and calculated heat input energy of the welds.

\begin{tabular}{|c|c|c|c|}
\hline \multirow[b]{2}{*}{$\begin{array}{c}\text { Test } \\
\text { number }\end{array}$} & \multicolumn{2}{|c|}{ Welding parameters } & \multirow[b]{2}{*}{$\begin{array}{c}\text { Welding heat } \\
\text { input energy, } \\
\mathrm{J} / \mathrm{mm}\end{array}$} \\
\hline & $\begin{array}{l}\text { Welding } \\
\text { current, } \\
\text { Amper }\end{array}$ & $\begin{array}{l}\text { Arc } \\
\text { voltage, } \\
\text { Volt }\end{array}$ & \\
\hline 1 & 200 & 26,5 & 1140 \\
\hline 2 & 255 & 26,5 & 1453 \\
\hline 3 & 255 & 32,0 & 1754 \\
\hline
\end{tabular}

After finishing the welding processes, the welds were cut perpendicular to the welding direction by using a power hacksaw. A $30 \mathrm{~mm}$ long piece from the beginning and the end of the weld were cut out. The remaining of the weld was cut into 6 equal specimens. The cut surfaces of the specimens were polished using 600, 800, 1000 and 1200 grade $\mathrm{SiC}$ abrasive papers. Then the specimens were etched using $8 \%$ nital solution to reveal the weld bead size and shape. The etched sections were scanned to $1000 \%$ of the original size in a scanner and each weld bead was photographed. The weld bead geometry parameters were measured by using a planimeter, a ruler and a protactor on the macrostructure image photograph. We obtained 12 different results for each welding condition. Simple averages of the results were calculated to determine each weld bead geometry parameter and the weld shape factor.

\section{RESULTS AND DISCUSSIONS}

The objective of this study is to find out relationships between main two FCAW welding parameters (welding current and arc voltage) and weld bead geometry parameters. The effects of welding parameters on the weld bead geometry were obtained from the measurements made on the weld bead photographs and calculations of some measured results. Figure 2 shows a typical macroscopic cross-section of a weld bead. 12 photographs were obtained for each weld bead. Simple averages of the measured results were calculated. These results are shown in Table 2. The bead cross-sectional area and the ratio of penetration depth to weld width for each weld were also calculated. The obtained results are given in Table 2. The experimental results were given in terms of figures for better explainations of the welding parameter effects. In each figure there are three results. The first result belongs to the first weld. The aim of the first weld was to form the basis of the following comparisons: The second weld represents the effect of the weld current. The heat input energy difference between the first weld and the second weld was created by raising the weld current from 200 Amperes to 255 Amperes as indicated in Table 1. The third weld represents the effect of the arc voltage. The heat input energy difference between the second weld and the third weld was created by raising the arc voltage from 26.5 volts to 32 volts as indicated in Table 1. Thus, comparing the three results of a figure will reveal the welding parameter effect on the weld bead geometry parameter. For example Chart-1 shows the relationships between the welding parameters and the weld penetration depth.

Table-2: Weld geometry parameters of the weld beads.

\begin{tabular}{|c|c|c|c|c|c|c|c|c|}
\hline $\begin{array}{c}\text { Test } \\
\text { num } \\
\text { ber }\end{array}$ & $\begin{array}{c}\mathbf{D} \\
\mathbf{m} \\
\mathbf{m}\end{array}$ & $\begin{array}{c}\mathbf{W} \\
\mathbf{m m}\end{array}$ & $\begin{array}{c}\mathbf{D} / \\
\mathbf{W}\end{array}$ & $\begin{array}{c}\mathbf{H} \\
\mathbf{m m}\end{array}$ & $\begin{array}{c}\mathbf{A}_{\mathbf{t}} \\
\mathbf{m m}\end{array}$ & $\begin{array}{c}\mathbf{A}_{\mathbf{m}} \\
\mathbf{m m}^{\mathbf{2}}\end{array}$ & $\begin{array}{c}\mathbf{A}_{\mathbf{d}} \\
\mathbf{m m}^{\mathbf{2}}\end{array}$ & $\begin{array}{c}\text { Angle, } \\
\text { degrees }\end{array}$ \\
\hline 1 & 2,1 & 12,5 & 0,1 & 3,58 & 42, & 15,7 & 26,8 & 41 \\
& 7 & 5 & 7 & & 60 & 8 & 2 & \\
\hline 2 & 3,1 & 12,5 & 0,2 & 4,88 & 64, & 20,2 & 43,7 & 64 \\
& 5 & 7 & 5 & & 06 & 6 & 9 & \\
\hline 3 & 3,1 & 16,3 & 0,1 & 3,54 & 65, & 26,8 & 38,3 & 37 \\
& 5 & 9 & 9 & & 20 & 7 & 3 & \\
\hline
\end{tabular}

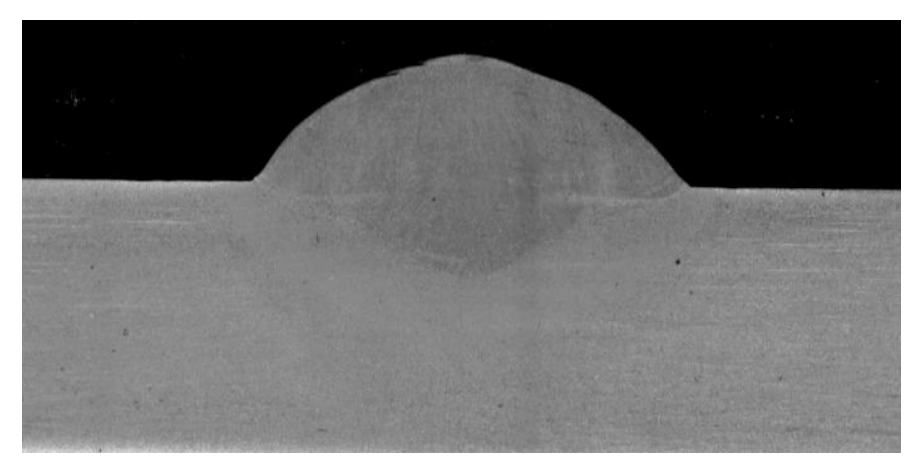

Fig-2: Typical macrography of a weld bead.

Penetration depth(D), weld width(W) and weld penetration depth to the weld width (D/W) ratio of the three welds are shown in Chart-1,2 and 3 respectively. Chart- 1 shows that there is a $45 \%$ difference between the first and the second weld. Raising the weld current resulted with a pronounced 
penetration depth increase. There is $313 \mathrm{~J} / \mathrm{mm}$ heat input difference between the second weld and the first weld as shown in Table 1. This energy difference was obtained by increasing the welding current. This energy difference produced the distinguished penetration depth difference between the welds. There is $301 \mathrm{~J} / \mathrm{mm}$ heat input difference between the third weld and the second weld as shown in Table 1. This extra welding energy didn't cause a penetration depth increase in the third weld. The results of Chart-1 indicate that the weld penetration depth is depended on the welding current and independent of the arc voltage. The effects of welding parameters on the weld width are shown in Chart-2. The second weld is a faintly wider than the first weld. There is a big difference between the third weld and the second one. The third weld is $30 \%$ wider than the second one. These results point out the important effect of the arc voltage on the weld width. Chart-3 shows how the welding parameters affect the weld shape factor (D/W ratio). The results of Chart-3 were directly produced from Chart- 1 and 2 results. Chart 3 indicates that deep welds are obtained with high welding current and shallow welds are produced with high arc voltage.

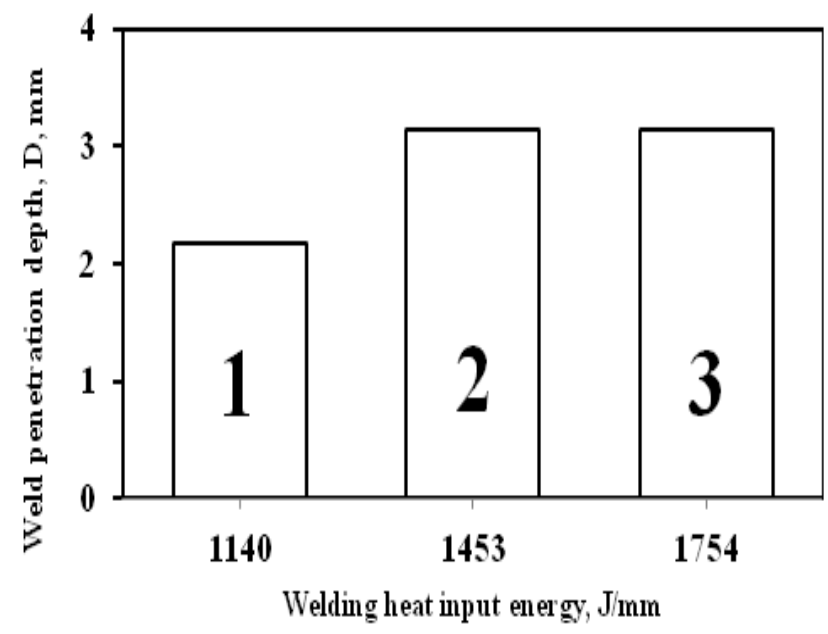

Chart-1: The effect of the welding heat input on the weld depth of penetration (D).

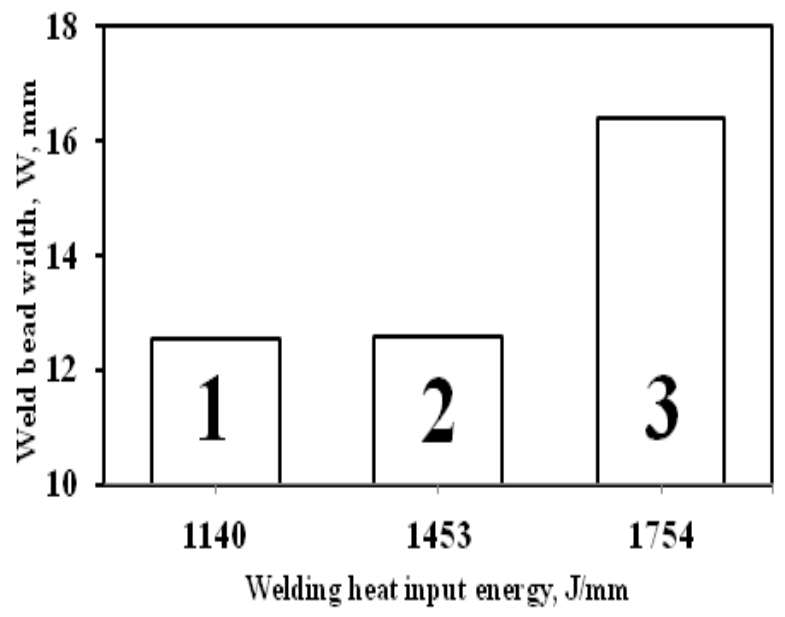

Chart-2: The effect of the welding heat input on the weld bead width $(\mathrm{W})$.

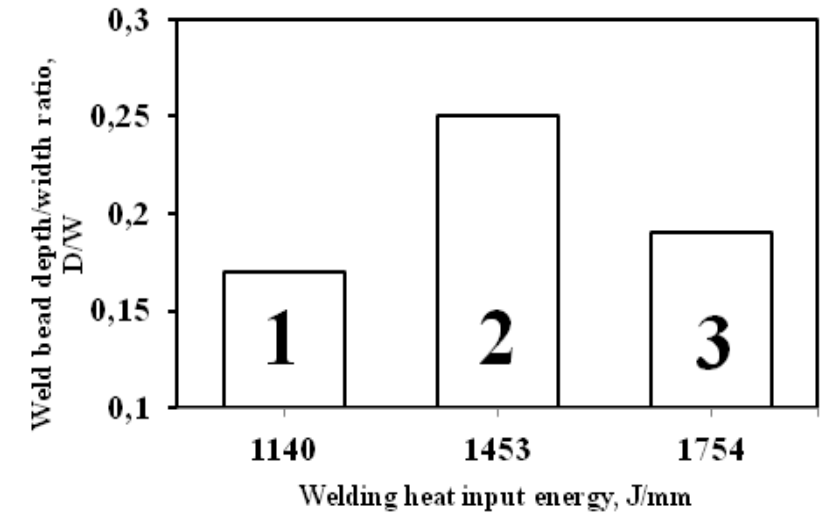

Chart-3: The effect of the welding heat input on the weld shape factor (D/W ratio).

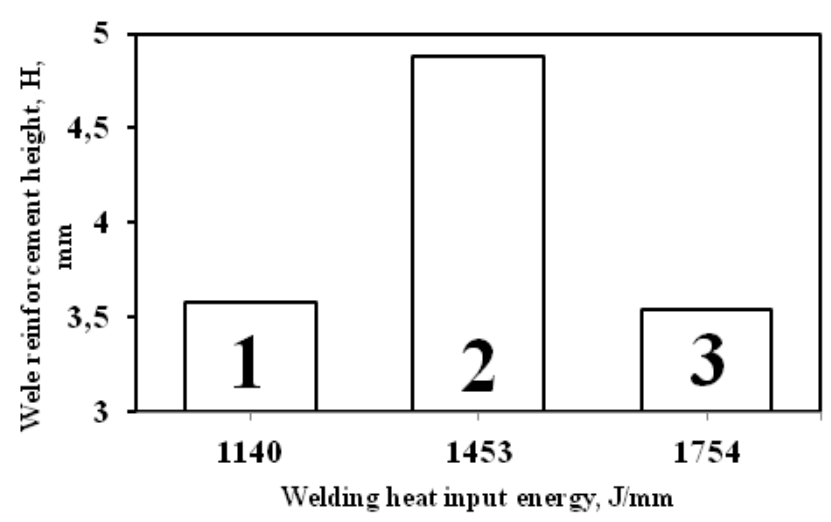

Chart-4: The effect of the welding heat input on the weld plate fusion area $\left(\mathrm{A}_{\mathrm{m}}\right)$.

Chart-4,5 and 6 inform how the welding parameters affect the weld bead area. Chart-4 shows that the plate fusion area $\left(\mathrm{A}_{\mathrm{m}}\right)$ is direct proportion to the welding heat input energy. Welding current and arc voltage have similar effects on $A_{m}$. Chart-5 instructs us how the welding parameters affect the electrode deposit area $\left(\mathrm{A}_{\mathrm{d}}\right)$. The electrode deposit area of the second weld is very big. The electrode deposit area increased with the current. Raising the welding current resulted with a high melted electrode volume and a big $A_{d}$.

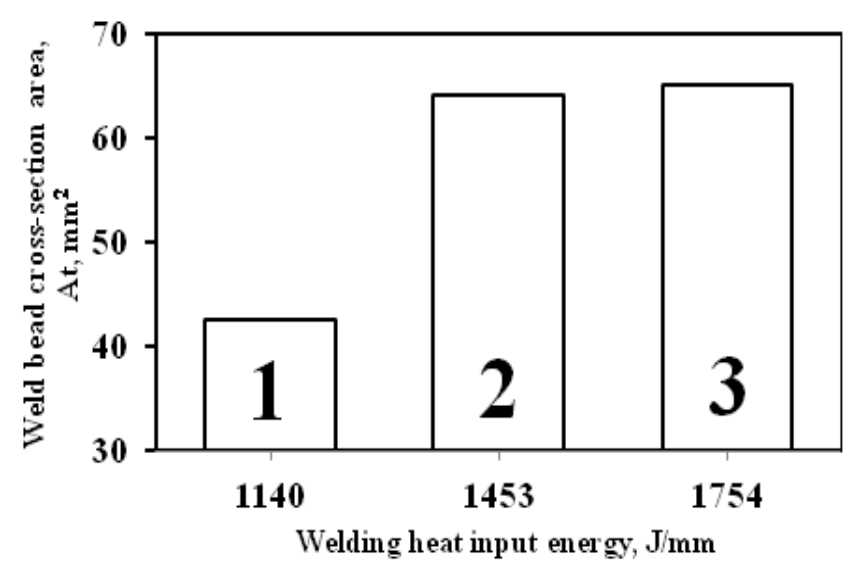

Chart-5: The effect of the welding heat input on the weld electrode deposit area $\left(\mathrm{A}_{\mathrm{d}}\right)$. 


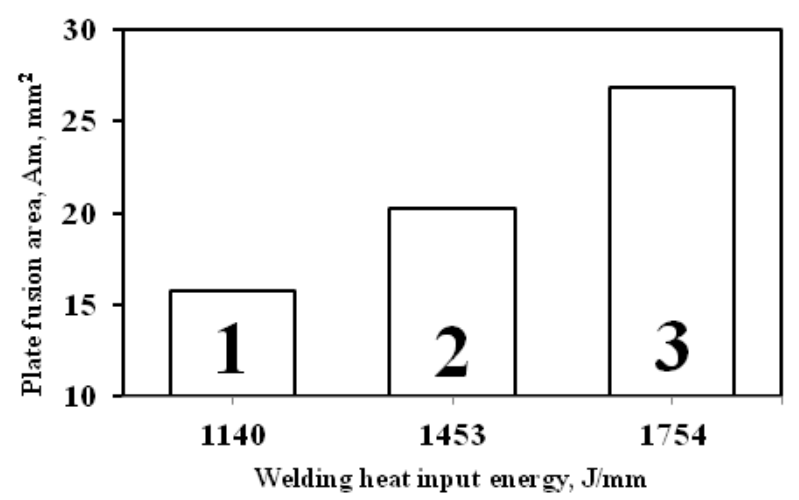

Chart-6: Figure 8. The effect of the welding heat input on the weld bead cross-section area $\left(A_{t}\right)$.

The electrode deposit area of the third weld is smaller than the second one. This result informs that less electrode is melted with the high arc voltage. It is evident that melting rate of the electrode decreases with increasing the arc voltage. Bead cross-section area $\left(A_{t}\right)$ of the welds are shown in Chart-6. There is a big increase with the welding current and a small increase with the arc voltage.

Chart-7 shows the effects of the welding parameters on height of reinforcement $(\mathrm{H})$. The second weld had a big $\mathrm{H}$ because, the electrode deposit area $\left(\mathrm{A}_{\mathrm{d}}\right)$ of this weld was very big as shown in Chart- 5 and its weld width didn`t change a lot with the welding current as shown in Chart-2. In the third weld the bead width grew 30\% (Chart-2) but the electrode deposit area showed an exiguous growth(Chart-5). Therefore the height of reinforcement $(\mathrm{H})$ of the third weld was very small than the second weld. It was even smaller than the first weld. The size of the weld width and the reinforcement height determine the wetting angle $(\theta)$ of the weld. The wetting angle increases with the height of reinforcement and decreases with the weld width. Therefore, the wetting angle of the second weld was big and the wetting angle of the third was small as shown in Chart- 8 . The welding current density of an electrode increases with the welding current [2]. In arc welding the heating and the melting rate of the electrode increases with the welding current density [38,39]. Melting of an electrode becomes easier if it is over heated. More electrode metal enters the liquid weld pool as the electrode melting rate increases [25].

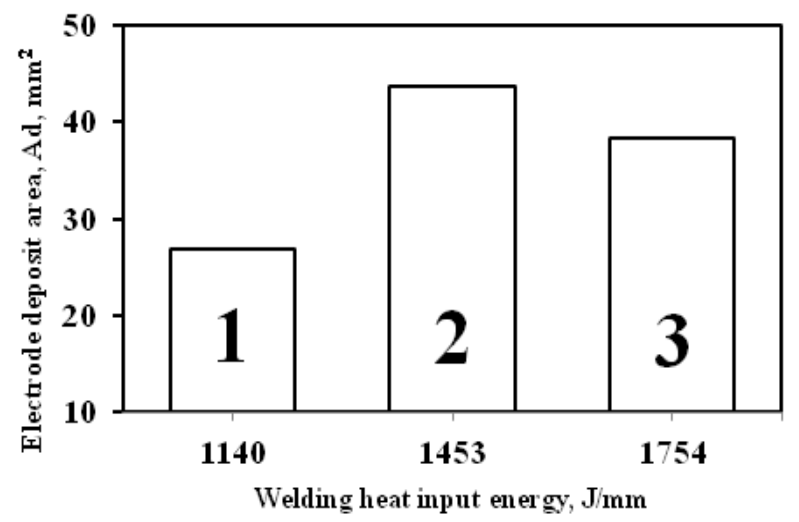

Chart-7: The effect of the welding heat input on the weld height of reinforcement $(\mathrm{H})$.
The electrode deposit area enlarges with increasing the welding current [40] as shown in Chart-5. The temperature of the droplets which are formed at the tip of the electrode rises with the welding current [41]. The size of the droplets decreases and their formation frequency increases with the droplet temperature [10]. The falling velocity of the droplets also increases with the temperature [42]. The momentum of the droplets increases with the welding current which affects the penetration depth. A deeper weld bead was obtained with the high welding current $[10,41]$. The second weld which had a higher welding current than the first one gave a deeper bead as shown in Chart-1. The electrode deposit area of the second weld was very big (Chart-5) because, more electrode was melted and more metal was trasferred to the weld pool. High amount of metal and hotter metal transfer to the welding pool caused a high heat input in the workpiece [41]. A higher energy input enlarged the melting volume of the workpiece. As a result the plate fusion area $\left(\mathrm{A}_{\mathrm{m}}\right)$ increased as shown in Chart-4. Although both the electrode deposit area and the plate fusion area enlarged with the welding current, their growing rates weren't equal. Their growing rates could be be calculated by the results given in Chart- 4 and 5 . The growth rate of $A_{m}$ was not as big as the $A_{d}$ growth rate. The weld current had a negligible effect on the weld width (Chart-3). The weld width grew slightly. This slight weld width grow affected D/W ratio, height of reinforcement $(\mathrm{H})$ and the wetting angle $(\theta)$. D/W ratio of the second weld was the biggest (Chart-3) [26] because, in this weld the weld depth increased but the width showed a very small increase. The big electrode deposit area growth of the second weld caused a high height of reinforcement $(\mathrm{H})$ (Chart-8) [43,44] and a high wetting angle (Chart-8) [27].

A raising in the arc voltage increases the heat input of the weld according to the Equation 1[36]. This increased heat input has a small effect on the electrode melting rate[10]. There are conflicting results about the effect of the arc voltage on the electrode melting rate. Gunaraj [45] identified a minor increase in electrode melting rate but, Ostsemin [39] stated a decreased melting rate. The electrode deposite area of the third weld was smaller than the second weld as shown in Chart-5. This resultant supported Ostsemin's results. The arc voltage mainly controls weld arc geometry [2]. The bottom diameter of the arc enlarges with the arc voltage [41].

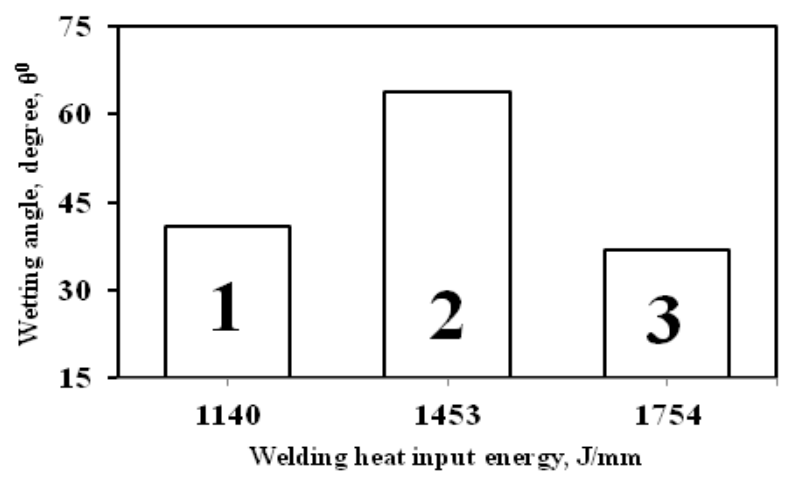

Chart-8: The effect of the welding heat input on the weld wetting angle $(\theta)$. 
The enlargement of the arc bottom causes more heating and melting at the surface of the workpiece $[42,46]$. Thus, a wider weld bead was obtained with a high arc voltage [27]. The third weld which has the highest arc voltage gave the widest weld bead (Chart-2). More heating at the surface of the workpiece causes more workpiece melting and a big plate fusion area [10]. The third weld which has the highest arc voltage gave the biggest plate fusion area as shown in Chart-4. The increased arc voltage doesn't change the droplet formation frequency at the tip of the electrode [41], droplet temperature [39], droplet falling velocity [41] and momentum of droplets [41]. Therefore, the penetration depth of the the third weld didn't increase with the heat input (Chart-1). In the third weld the height of reinforcement $(\mathrm{H})$ was small (Chart-7) because, the bead width increased and the electrode deposit area decreased with the arc voltage. The wetting angle was also decreased (Chart-8) according to the profile of the weld bead [42].

\section{CONCLUSIONS}

In this article, an experimental study was conducted to investigate the influence of welding parameters in FCAW process particularly welding current and arc voltage on weld bead dimensions. From the above investigations following conclusions have been drawn:

- Melting rate of a FCAW electrode increases with the welding current and it decreases with the arc voltage.

- The plate fusion area depends on the heat input of the weld.

- The height of reinforcement(H), the depth of penetration(D) and the wetting angle $(\theta)$ increase with the welding current.

- The arc voltage increases the weld width.

\section{ACKNOWLEDGEMENT}

This work has been supported by the Scientific Research Project Program of Marmara University.

\section{REFERENCES}

[1]. Jeffus, L. 2004. Welding Principles and Applications.5th Edition, Delmar Learning, New York

[2]. Cary, H.B., Helzer, S.C. 2005. Modern WeldingTechnology, Prentice Hall, New York.

[3]. Blodgett, O.W., Funderburk, R.S., Miller, D.K., Quintana, M., 1999. Fabricators and Erectors Guide toWelded Steel Construction, The James F. Lincoln ArcWelding Foundation, Cleveland,

[4]. Nowacki, J., Maciej, U.M., Zajac, P. 2009. FCAWwelding of duplex steel in construction of chemical

[5]. argo carriers, Welding International, 23, 3442.Mitchell,K.C. 2003. The Application of Flux Cored Arc Welding (FCAW) in UK Power Plant, Operation Maintenance and Materials, 2, 1-7,

[6]. Aloraier, A., Al-Mazrouee, A., Price, J.W.H., Shehata,T. 2010. Weld Repair Practices Without Post Weld Heat Treatment for Ferritic Alloys and Their
Consequences on Residual Stresses, International Journal of Pressure Vessels and Piping, 87,127-133.

[7]. Alorairer,A., Ibrahim, R., Thomson, P. 2006. FCAW Process to Avoid the Use of Post Weld Heat Treatment, International Journal of Pressure Vessels and Piping, 83, 394-398.

[8]. Palani, P. K., Murugan, N., Karthikeyan,B., 2006 Process Parameter Selection for Optimizing Weld Bead Geometry in Stainless Steel Cladding Using Taguchi's Approach", Materials Science and Technology, 22, 1193-1200.

[9]. Palani, P. K., Murugan, N. 2008. Ferrite number optimisation for stainless steel cladding by FCAW using Taguchi technique, International Journal of Materials and Product Technology, 33, 404-420.

[10]. Yukler, I., Calis, I. 1999. Weld Bead Geometry, MUTEF Publications, İstanbul.

[11]. Huang, H. Y. 2010. Effects of activating flux on thewelded joint characteristics in gas metal arc welding Materials and Design, 31, 2488-2495.

[12]. Pierce S.W., Burgardt P., Olson D.L. 1999. Thermocapillary and Arc Phenomena in Stainless Steel Welding, Welding Journal, 78, 45-52.

[13]. Karunakaran N., Balasubramanian V. 2011. Effect ofpulsed current on temperature distribution, weldbead profiles and characteristics of gas tungsten arc welded aluminium alloy joints, Transactions of Nonferrous Metals Society of China, 21, 278-286.

[14]. Abbasi, K., Alam, S., Khan, M.I. 2012. An Experimental Study on the Effect of MIG Welding parameters on the Weld-Bead Shape Characteristics, Engineering Science and Technology, 2, 599-602.

[15]. Murugan, N., Gunaraj, V. 2005. Prediction and Control of Weld Bead Geometry and Shape Relationships in Submerged Arc Welding of Pipes, Journal of Materials Processing Technology, 168, 478-487,

[16]. Dey, V., Pratihar, D.K., Datta, G.L., Jha, M.N., Saha, T.K., Bapat, A.V. 2009. Optimization of Bead Geometry in Electron Beam Welding Using a Genetic Algorithm, Journal of Materials Processing Technology, 209, 1151-1157,

[17]. Sandor, T.,Dobranszky, J. 2007. The Experiences of Activated Tungsten Inert Gas (A-TIG) Welding Applied on 1.4301 Type Stainless Steel Plates, Materials Science Forum, 63-70, 537-538.

[18]. Bauer, B., Topi, A., Kralj, S., Ko`uh, Z. 2011. Influence of The Gas Composition on the Geometry of Laser-Welded Joints in Duplex Stainless Steel, Materials and Technology 45, 413-419.

[19]. De, A., Jantre, J., Ghosh, P.K. 2004. Prediction of Weld Quality in Pulsed Current GMAW Process Using Artificial Neural Network, Science and Technology of Welding and Joining 9, 253-259.

[20]. Benyounis, K.Y., Olabi, A.G. 2008. Optimization of Different Welding Processes Using Statistical and Numerical Approaches, Advances in Engineering Software, 39, 483-496,

[21]. Raveendra, J., Parmar, R.S. 1987. Mathematical Models to Predict Weld Bead Geometry for Flux 
,Cored Arc Welding, Journal of Metal Construction, 19(2), 31R-35R.

[22]. Mostafa, N.B., Khajavi, M.N., "Optimization of Welding Parameters for Weld Penetration in FCAW", Journal of Achievements in Materials and Manufacturing Engineering, Cilt 16, Issue 1-2, MayJune, 2006.

[23]. Rodrigues, L.O., Paiva, A.P., Costa, S.C. 2009. Optimization of the FCAW Process by Weld Bead Geometry Analysis", Welding International, 23, 261-269,

[24]. Starling, C.M.D., Modenesi, P.J., Borba, T.M.D2010. Bead Characterization on FCAW Welding of a Basic Tubular Wire, Welding International, 24, 485-498.

[25]. Kannan,T., Murugan,N. 2006. Effect of Flux Cored Arc Welding Process Parameters on Duplex Stainless Steel Clad Quality, Journal of Materials Processing Technology, 176, 230-239.

[26]. Palani, P. K., Murugan, N. 2006. Development of Mathematical Models for Prediction of Weld Bead Geometry in Cladding by Flux Cored Arc Welding", International Journal of Advanced Manufacturing Technology, 30, 669-676.

[27]. Palani, P. K., Murugan, N. 2007. Optimization of Weld Bead Geometry for Stainless Steel Claddings Deposited by FCAW", Journal of Materials Processing Technology, Cilt 190, 291-299,

[28]. Ghazvinloo, H.R., Honarbakhsh, R. 2010. Effect of Gas Shielded Flux Cored Arc Welding Parameters of Weld Width and Tensile Properties of Weld Metal in a Low Carbon Steel", Journal of Applied Sciences, 10, 658-663.

[29]. Palani, P. K., Murugan, N. 2007. Modelling and Simulation of Wire Feed Rate for Steady Current and Pulsed Current Gas Metal Arc Welding Using 317L Flux Cored Wire", International Journal of Advanced Manufacturing Technolgy, 34, 1111-1119.

[30]. Badheka,V.J. 2013. Effect of Metal-cored Arc Welding Process Parameters on Weld Bead Geometry, Welding and Cutting, (12), 106-111.

[31]. Gomes, J.H.F., Paiva, A.P.,Costa, S.C., Balestrassi, P.P. , Paiva E.J. 2013. Weighted Multivariate Mean Square Error for processes optimization: A case study on flux-cored arc welding for stainless steel claddings, European Journal Research, 226, 522-535

[32]. Kumar V.V., Murugan N. 2011. Effect of FCAW Process Parameters on Weld Bead Geometry in Stainless Steel Cladding, Journal of Minerals \& Materials Characterization \& Engineering, 10, 827842 ,

[33]. Mohamata S.A., Ibrahima I.A., Amira A., Ghaliba A. 2012. The Effect of Flux Cored Arc Welding (FCAW) processes on different parameters, Procedia Engineering, 41, 1497-1501.

[34]. Sadek A., Ibraham R.N., Price J.W.H., Shehata T., Ushio M. 2001. Effect of welding parameters of FCAW process and shielding gas type on weld bead geometry and hardness distribution, Transactions of Japan welding research institute, 30, 45-52
[35]. Aloirer,A., Almazrouue,A., Shehata,T., Price,J.W.H. 2011. Role of Welding Parameters Using the Flux Cored Arc Welding Process of Low Alloy Steels on Bead Geometry and Mechanical Properties, Journal of Materials Engineering and Performance, 20, 1-8.

[36]. Kou,S. 2003. Welding Metallurgy,2nd Edition, John Wiley and Sons, New York.

[37]. Matos,N.C. 2012. Welding Procedures Specification for FCAW of Wind Towers, M.Sc. Thesis, Tecnico Lisboa.

[38]. Singh, R.P., Garg, R.K., Shukla, D.K. 2012. Parametric Effect on Mechanical Properties in Submerged Arc Welding Process, International Journal of Engineering Science and Technology, 4, 747-757.

[39]. Ostsemin,A.A. 2010. Melting Rate of Electrode Wire in Arc Welding, Russian Engineering Research, (30), 677-679

[40]. Chandel R.S., Seow H.P., Cheong F.L. 1997. Effect of increasing deposition rate on the bead geometry of submerged arc welds, Journal of Materials Processing Technology, 72, 124-128.

[41]. Lancaster,J.F. 1993. The Physics of Welding, 2nd Edition, Pergamon Press, New York,

[42]. Murugan, N., Gunaraj, V. 2005. Prediction and Control of Weld Bead Geometry and Shape Relationships in Submerged Arc Welding of Pipes, Journal of Materials Processing Technology, 168, 478-487,

[43]. Kolahan, F., Heidari, M. 2011. A new Approach for Predicting and Optimizing Weld Bead Geometry in GMAW, International Journal of Aerospace and Mechanical Engineering, 5, 138-142.

[44]. Gomes, J.H.F., Costa, S.C., Paiva , A.P., Balestrassi, P.P. 2012. Mathematical Modelling of Weld Bead Geometry, Quality and Productivity for Stainless Steel Claddings Deposited by FCAW, Journal of Materials Engineering and Performance, 21, 918923,

[45]. Gunaraj, V., Murugan, N. 1999. Application of Response Surface Methodology for Predicting Weld Bead Quality in Submerged Arc Welding of Pipes, Journal of Materials Processing Technology, 88,266275 .

[46]. Singh, K., Pandey, S. 2009. Recycling of slag to act as a flux in submerged arc welding, Resources, Conservation and Recycling, 53, 552-558. 